\title{
Social Work Practices for Children, Youth and Families in Portugal: Challenges and Approaches
}

\author{
Fernando H. Serra ${ }^{1} \cdot$ Maria I. Carvalho ${ }^{1} \cdot$ Carla Pinto $^{1} \cdot$ Mary E. Rauktis $^{2}$ (i)
}

Published online: 6 May 2019

(c) Springer Science+Business Media, LLC, part of Springer Nature 2019

This special issue of Child and Adolescent Social Work Journal addresses the system of protection and intervention with children, adolescents and families in Portugal, a southern European country and a state-member of the European Union. With it, we seek to highlight the research and innovative practices by social workers and other professionals. Why should Portugal be featured in an American edited journal of social work? One of the editors has spent approximately 15 years collaborating with Portuguese social workers and has witnessed how social work, a profession once part of the state system of oppression, has developed into one of advocacy and ethical practices, and from one of technical skills to a disciple with its own research.

To provide context to those unacquainted with Portugal, the first legislation aimed at protecting children was created in the context of the liberal democratic ideals of the republican revolution in 1910 (Ferreira, 2011; Tomé, 2016). However, despite good intentions, vulnerable children continued to be sent to the asylums and "correction houses". This model prevailed with small changes during the following decades, especially in the dictatorship regime (1926-1974). The Revolution of April 1974, finally instituted the modern democracy and with it began a slow process of creating a genuine child protection system (Ferreira, 2011). Yet, the focus remained on the institutionalization of children and not on community and preventative approaches.

Following the Convention on the Rights of the Child in 1989 , the system was reconfigured, in order to reinforce the principle of "best interests of the child", and calling for the active participation of the community in co-responsibility between the State and community organizations to protect

Mary E. Rauktis

Mar104@pitt.edu; maryrauktis@gmail.com

1 Instituto Superior De Ciencias Sociais e Politicas, Universidade de Lisboa, Lisbon, Portugal

2 University of Pittsburgh, School of Social Work, Pittsburgh, PA, USA and promote the rights of children and young people. Under this new vision were created the Commissions for the Protection of Children and Youth (CPCJ). The commissions follow a set of principles enshrined in the international conventions on children's rights, namely: their superior interest, privacy, early intervention, minimum intervention, parental responsibility, and preservation of affective relations, prevalence of compulsory information and compulsory listening and information. These commissions are coordinated at central government level but are developed regionally and locally. These are competent to implement promotion and protection measures whenever parents have their consent, namely: support for parents; support with another relative; trust the right person; support for the autonomy of life; foster care and residential care. These measures are only possible if there is parental consent, if this is not the case, go to court and the court will apply the measure for the protection of children.

As in other countries, intervention with children, young people and their families is a complex and very challenging area for social workers (Magalhães, 2002; Melo \& Alarcão, 2010; Carvalho 2015). Practitioners intervene in these commissions in a multidisciplinary framework and institutional networks. They assess the risk and define the strategies that must be ensured to protect children in the light of their best interests (Melo \& Alarcão, 2011. They also must have relational and resilience skills to work with children, families and those who host these children-families and institutions. In this context, ethical sensitivity is a crucial professional competence (Ferreira, 2011). Social workers have a social responsibility to society and to the people with whom they intervene. In their advocacy, they have to challenge unjust policies. For example, criticizing the policies and organizations that house and protect children, but which hold them hostage to their services, making it impossible for children to experience the environment of a foster or adoptive family. Many interventions at this level give primary rights to the biological family undermining the fundamental principle of 
children that is the right to a family. This is a challenge for the social workers.

Social work with children and youth has been challenged most recently by the economic and financial crisis that began in the late 2000s. Portugal was severely hit by 2008 crises and subsequent counteraction measures, and underwent strong austerity policies imposed by international financing and regulatory agencies (Governo da República Portuguesa, 2011). Portuguese state services and non-profit social organizations had to look for new ways of tackling social problems and needs (González \& Figueiredo, 2015). The austerity regime, imposed most forcedly between 2011 and 2014, affected particularly children and youth, with family diminishing resources and public services cut back or eliminated (Wall et al., 2015). Although austerity policies have been softened since 2015 under a left wing government, some argue that they have not completely disappeared from public policies options or rhetoric, and we can still perceive the press to innovate and deliver services with lesser public resources.

In this special edition of Child and Adolescent Social Work Journal, we sought to reveal some of these concerns raised in the Portuguese context. The articles presented in this special edition focus particularly on residential care, mental health and well-being, early intervention, and health promotion.

In her article "Health promotion of children and young adults who live in residential care institutions in Portugal", Julião (2019) analyzes health promotion for children and young adults who live in residential care institutions in Portugal. The results showed that the organizations are concerned with the health promotion of children and youths in care, as well as their families and staff, offering services via access to public services, but also based on their own resources and partnerships with private health institutions. The health promotion activities are especially related to mental and oral health, since in these areas the public system seems more lacking.

Three articles are from the national study of the quality of residential care being conducted in Portugal. Campos et al. (2019) highlight mental health issues in the article "Emotional and behavioral problems and psychosocial skills in adolescents in residential care", which compared adolescents in residential care in Portugal, with Portuguese normative data regarding the incidence of mental health problems and their psychosocial skills. The results show that the adolescents in residential care presented higher levels of mental health problems, lower academic achievement and a poorer social support network. Furthermore, their psychosocial skills were negatively correlated with mental health problems. These findings are consistent with the need to assess for mental health problems in adolescents in residential care as early as possible in order to prevent further vulnerabilities and to support resilience. Mental health and well-being is also the focus of Rodrigues et al. (2019) article "Psychological adjustment of adolescents in residential care: Comparative analysis of youth self-report/strengths and difficulties questionnaire". Since YSR and SDQ are the most commonly used self-report instruments for screening of problems and the assessment of psychological adjustment of youth, the article analyzes their comparative utility specifically in the context of residential care. The results showed indeed that the youngsters in residential care presented more signs of maladjustment than their normative counterparts. Significant correlations were found between the two self-report measures and also with some context and youngsters' variables, supporting the utility of the simultaneous use of these two instruments. In the final paper in the group, Soares et al. (2018) explore the child perspective in the article "Adoptionrelated gains, losses and difficulties: The adopted child's perspective". Results show that adopted children identified four main gains inherent to the experience of being adopted. The most frequent were related to being part of a family and experiencing family life. Adoptees identified losses related to their pre-adoption life, particularly birth family loss (parents and siblings), and previous relationships loss (especially school peers). Most adoptees reported facing family and social relationships difficulties in their post-adoption life, such as communicating openly about adoption with the adoptive parents and peers. Findings showed that children's adaptation to adoption is complex, ambivalent and individually experienced. Altogether, these articles suggest that residential care, which is the predominant model in Portugal, experiences challenges in providing services beyond care and nurturance.

Two articles focus on family focused support and care for very young children, and one on adolescent parenting. Nata and Cadima (2019), describe "Parent- and FamilyFocused Support in Portugal: Context and Analysis of Services/Programs from an equity perspective. The article provides a critical overview of evidence-based and promising parent- and family-focused support programmes currently implemented in Portugal. Several review procedures along with expert consultation allowed for the identification of 11 programmes for family and parenting support. These programmes were then analysed with regard to empirical support for their effectiveness, and scrutinized for key features and principles that were helpful in tackling social and educational inequalities.

Family-centred practices are also the focus of the article by Dias and Cadime (2019), "Child and family-centered practices in early childhood education and care services: an empirical study with families and practitioners in Portugal". This work aims to explore families' and practitioners' perspectives about child/family centered practices and related variables. Overall, the practices were more centered on the 
children than centered on families, although some differences were observed as a function of the practitioners' training or professional experience. Data gathered from families reinforced that children's centered practices were the most prevalent, given that families indicated that intervention consisted mainly on providing information about children's predicable development, as well as about the functioning of the services. Family functioning related with conflicts and parental discipline with adolescents is the focus of Relva et al. (2019) article "Sibling conflict and parental discipline: The mediating role of family communication in Portuguese adolescents". The research finds the links among different parental discipline dimensions, family communication, and sibling conflict resolution. Altogether these three articles highlight the importance of engaging with parents in a purposeful way, throughout the family life cycle.

Alves et al. (2019) in "Developing a functional code system to analyse forensic interviews with suspected victims of child sexual abuse" created a forensic tool to be used with suspected victims of abuse in Brazil. (This article is the only one that is not from Portugal. Although the call was for all Portuguese-speaking countries, we were not able to obtain the diversity of experiences originally intended. Nevertheless, we decided to keep Alves and Young's article respecting the original objective). The article describes the efforts to create a respectful and functional coding system to analyse forensic interviews with children alleged to have been sexually abused. The findings show the forensic interviewers frequently used recognition memory prompts rather than probing children's free recall memory, however free recall memory probes were positively correlated with disclosure of new information while recognition memory probes were positively correlated with uninformative utterances. This suggests that Brazilian child investigations need to train and coach their investigators in performing interviews which encourage children to speak freely and openly disclose information.

The last two articles illustrate projects developed in school contexts, for health promotion and prevention of substance addictions. Silva and Teles (2019) in their article "Health promotion in children and youth: Contributions of social work in building collaborative networks in schools in Portugal" present a school social work intervention named Health Platform at School and the work developed by the municipality of Cascais in this platform. The project is based on a collaborative partnership network where social work develops a collective intervention for health promotion among children and young people. The authors emphasize the collective action dimension of social work with children and young people for enhancing their empowerment, both at individual and structural levels.

Finally Real and Vieira (2019), in their article "Psychoactive substance abuse in adolescence and social work in the school: A point a view from professionals and students in Castelo Branco, Portugal", describe a research in social work school intervention which underline the importance of preventive social intervention programs to tackle substance abuse by adolescents. They used a qualitative approach to explore the adolescent's life experience with drug abuse and their perception about their participation in school preventive social programs. The authors concluded that it is important to implement at an early life stage nonspecific drug use preventive activities, through practices that do not focus only on drugs and consumption behaviours, but rather interventions that seek the adolescents' integral psychosocial development and empowerment.

\section{Compliance with Ethical Standards}

Conflict of interest The authors declare no conflict of interest, and no research was done for this editorial.

\section{References}

Alves, R. T., Jr., Nelson-Gardell, D., Tavares, M., \& Young, T. L. (2019). Developing a functional code system to analyse forensic interviews with suspected victims of child sexual abuse. Child and Adolescent Social Work Journal. https://doi.org/10.1007/ s10560-019-00612-z.

Campos, J., Barbosa-Ducharne, M., Dias, P., Rodrigues, S., Martins, A. C., \& Leal, M. (2019). Emotional and behavioral problems and psychosocial skills in adolescents in residential care. Child and Adolescent Social Work Journal. https://doi.org/10.1007/ s10560-018-0594-9.

Carvalho, M. I. (2015) (Coord.). Serviço Social com Famílias. Lisboa: Pactor.

Dias, P. C., \& Cadime, I. (2019). Child and family-centered practices in early childhood education and care services: An empirical study with families and practitioners in Portugal. Child and Adolescent Social Work Journal. https://doi.org/10.1007/s 1056 0-019-00599-7.

Ferreira, J. M. L. (2011). Serviço Social e Modelos de Bem-Estar para a Infância. Modus Operandi do Assistente Social na Promoção da Proteção à Criança e à Família. Lisboa: Quid Juris.

González, P., \& Figueiredo, A. (2015). The European Social Model in a contexto of crises and austerity in Portugal. In D. VaughanWhitehead (Ed.), The European social model in crisis. Is Europe losing its souls? (pp. 386-450). Cheltenham: Edward Elgar Pub.

Governo da República Portuguesa. (2011). Memorando de Entendimento sobre as Condicionalidades de Política Económica.17demaiode2011. Disponívelem: Retrieved from http://www.portugal.gov.pt/media/371372/mou_pt_20110517.pdf.

Magalhães, T. (2002). Maus Tratos em Crianças e Jovens. Guia prático para profissionais. Lisboa: Quarteto.

Melo, A., \& Alarcão, M. (2010). Avaliação da qualidade do planeamento do modelo de avaliação e intervenção familiar integrada para os centros de apoio familiar e de aconselhamento parental. Psicologia, 24(2), 197-218. 
Melo, A. T., \& Alarcão, M. (2011). Avaliações em situações de risco e perigo para as crianças: Um roteiro organizador. Análise Psicológica, 29(3), 451-466.

Nata, G., \& Cadima, J. (2019). Parent- and family-focused support in Portugal: Context and analysis of services/programmes from an equity perspective. Child and Adolescent Social Work Journal. https://doi.org/10.1007/s10560-019-00613-y.

Real, D., \& Vieira, R. (2019). Psychoactive substance abuse in adolescence and social work in the school: A point a view from professionals and students in Castelo Branco, Portugal. Child and Adolescent Social Work Journal. https://doi.org/10.1007/s1056 0-019-00603-0.

Relva, I. C., Alarcão, M., Fernandes, O. M., Carvalho, J., \& Fauchier, A. (2019). Sibling conflict and parental discipline: The mediating role of family communication in Portuguese adolescents. Child and Adolescent Social Work Journal. https://doi.org/10.1007/ s10560-019-00600-3.

Rodrigues, S., Barbosa-Ducharne, M., Del Valle, J. F., \& Campos, J. (2019). Psychological adjustment of adolescents in residential care: Comparative analysis of youth self-report/strengths and difficulties questionnaire. Child and Adolescent Social Work Journal. https://doi.org/10.1007/s10560-019-00614-x.
Silva, T. R., \& Teles, H. (2019). Health promotion in children and youth: Contributions of social work in building collaborative networks in schools in Portugal. Child and Adolescent Social Work Journal. https://doi.org/10.1007/s10560-019-00606-x.

Soares, J. L., Ralha, S., Ducharne, M. B., \& Palacios, J. (2018). Adoption-related gains, losses and difficulties: The adopted child's perspective. Child and Adolescent Social Work Journal. https://doi. org/10.1007/s10560-018-0582-0.

Tomé, M. R. (2016). Questão da infância e juventude em Portugal: marcos e marcas de um século de proteção sócio judicial. In M. Braz (Ed.), Serviço Social Portugal- Brasil: Formação e exercício em tempos de crise. Papel Social: Campinas.

Wall, K., de Almeida, A. N., Vieira, M. M., Cunha, V., Rodrigues, Leonor, Coelho, F., ... Atalaia, S. (2015). Impactos da crise nas crianças portuguesas: indicadores, políticas, representações. Lisboa: ICS. Imprensa de Ciências Sociais.

Publisher's Note Springer Nature remains neutral with regard to jurisdictional claims in published maps and institutional affiliations. 